\title{
Bacteriological Status of Street Foods in Different University Premises of Dhaka City, Bangladesh
}

\author{
Nafisa Tanjia ${ }^{1}$, Nahida Akhter ${ }^{1}$, Ajoy Roy ${ }^{1}$, Mir Shefaly Akhter ${ }^{1}$, Muniruddin Ahmed ${ }^{2}$, Sufia Islam*1 \\ ${ }^{I}$ Department of Pharmacy, East West University, Dhaka-1212, Bangladesh; ${ }^{2}$ Department of Clinical Pharmacy and Pharmacology, University of Dhaka, Dhaka \\ 1000, Bangladesh
}

\begin{abstract}
Street food contamination is common and has a potential health hazards throughout the world. These categories of foods are very popular among the students of Academic Institutions (Universities) of Dhaka city, Bangladesh for their appealing look and reasonable cost. This study was conducted to determine the presence of $E$. coli, Shigella sp. and Vibrio sp. in the street foods. Two hundred and forty-two food samples were collected from 20 University premises of Dhaka city. Biochemical tests were performed on suspected colonies for the identification of the relevant bacteria obtained from the samples. $E$. coli, Vibrio sp., and Shigella sp. were identified in $18 \%$ samples, where $E$. coli was found in $12 \%$, Vibrio sp. was identified in $5 \%$, and Shigella sp. in $<1.0 \%$ food sample studied. The samples from which $E$. coli and food borne pathogens were obtained were considered unsatisfactory for human consumption. Presence of enteric bacteria in street foods indicates that the students of different Universities in Dhaka city might be at high risk of food borne disease.
\end{abstract}

Keywords: Street-vended food; Microbiological hazards; Food contamination; E. coli; Shigella sp.; Salmonella sp.; Vibrio sp.

This present study is a continuation of our previous findings where we identified pathogenic organisms in street foods sold around the University premises ${ }^{1}$. Street foods are usually vended in stalls, roadside stands, different types of push-carts, hawker with loads. A large number of people prefer these foods because of the accessibility, reasonable cost, good taste and to some extent for its nutritional value ${ }^{2,3}$. However, these foods can be contaminated from the raw materials to the storage and distribution ${ }^{4}$. Different studies highlighted the potential role of food borne illnesses due to consumption of street foods ${ }^{5-9}$. Also the organisms present in different types of street food samples were identified as Multidrug resistant ${ }^{10}$. Food spoilage is another reason of contamination because of its long exposure on roadsides while vending 2,3 .

In our previous study, it was observed that the street vended foods, collected from East West

University premises were contaminated with different types of enteric bacteria such as; E. coli, Salmonella sp., Shigella sp. and vibrio $\mathrm{sp} .{ }^{1}$. At that time, we selected only one University premises where street foods are sold enormously. However, due to our shortage of resource we could not carry out microbiological evaluation of street foods in other University premises. It is also important to assess the food quality in other University areas. Therefore, the objective of this study was to identify the food contamination in street vended foods, obtained from twenty different University premises. In addition, this study also evaluated seasonal distribution of different organisms in contaminated street food samples.
The total number of different street vended food samples was 242 (Table 1). About $200 \mathrm{~g}$ of each sample was taken in sterile sealed poly bags from 20 University premises in Dhaka city. Samples were carried to the laboratory within 2-3 hours of collection then these were processed.

Table 1: Food category of collected street food samples from different University premises $(n=242)$

\begin{tabular}{lc}
\hline Food category & No. of samples \\
\hline Deep Fried and fried Items & 109 \\
Spicy and sour items & 44 \\
Sweet and baked items & 82 \\
Rice and noodles items & 7 \\
\hline
\end{tabular}

For E. coli isolation, $5 \mathrm{~g}$ (for solid and semi-solid) or, $5 \mathrm{ml}$ (for liquid) were blended with $45 \mathrm{ml}$ of Trypticase Soy Broth (TSB) and $0.3 \%$ yeast extract (YE) and were incubated at $37^{\circ} \mathrm{C}$ for 18 24 hours for enrichment. These broths were then inoculated onto TBX (Tryptone Bile X-glucuronide) and MacConkey agar plates and were incubated at $37^{\circ} \mathrm{C}$ for $18-24$ hours.

For isolation of Shigella sp., and Salmonella sp., food samples were homogenized with $45 \mathrm{ml}$ of BPW (Buffered Peptone Water) broth and were incubated at $37^{\circ} \mathrm{C}$ for $18-24$ hours. Enriched broths were then used to inoculate onto two agar plates, namely BGA (Brilliant Green Agar) and XLD (Xylose Lysine Deoxycholate) and were incubated at $37^{\circ} \mathrm{C}$ for $18-24$ hours. 
For the Vibrio sp., $45 \mathrm{ml}$ of APW (Alkaline Peptone Water) was mixed with homogenized samples and incubated at $37^{\circ} \mathrm{C}$ for 18 24 hours for the purpose of enrichment. Enriched broths were then inoculated in TCBS (Thiosulfate Citrate Bile salts Sucrose) and incubated at $37^{\circ} \mathrm{C}$ for $18-24$ hours.

Different types of biochemical tests such as KIA (Kligler's Iron Agar), MIO (Motility, Indole, Ornithine), Catalase, Oxidase, Urease test etc. were performed by standard laboratory methods (World Health Organization, 1987).

Table 1 shows different types of food categories which were collected from different University premises. The food categories were deep fried and fried $(n=109)$; spicy and sour $(n=44)$; sweet and baked $(n=84)$ and rice and noodles $(n=7)$.

Street food samples from twenty different Universities showed the presence of three types of microorganisms (E. coli, Shigella sp. and Vibrio sp.). E. coli was identified in majority contaminated samples (29 samples), Vibrio sp. was observed in twelve samples and only two samples were identified with Shigella sp. $(<1.0 \%)$. Among 43 food samples, 13\% (deep fried and fried items) and $12 \%$ (sweet and baked items) were contaminated with $E$. coli. Contamination with E. coli $(20 \%)$ was found in spicy and sour items of collected samples (Figure 1). Our results (Figure 2) showed seasonal distribution of different organisms in food

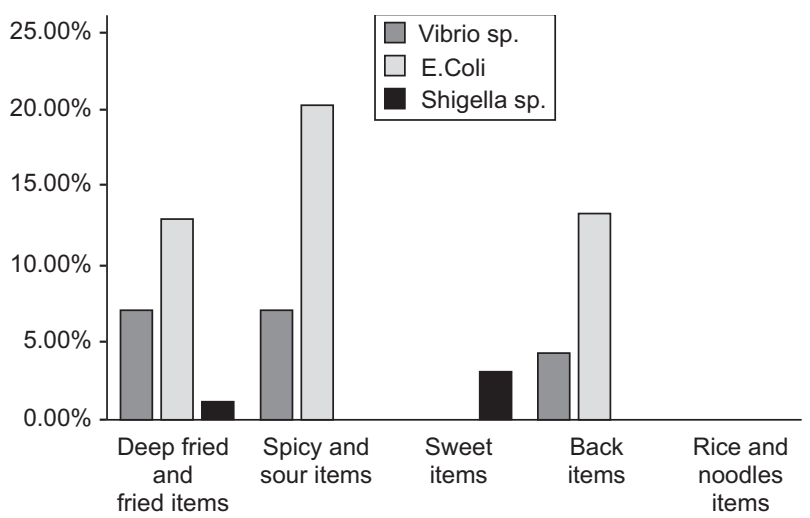

Figure 1. Food samples (\%) contaminated with microorganisms $(n=242)$

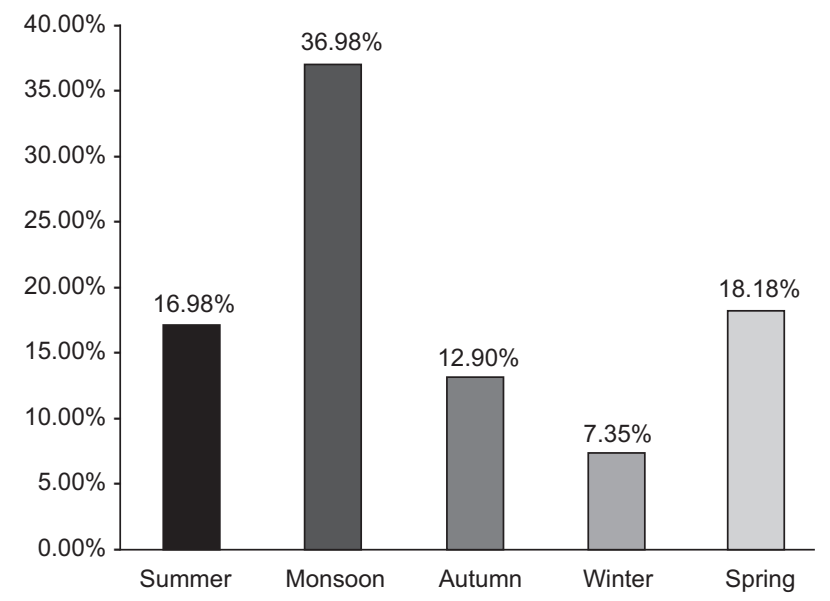

Figure 2. Seasonal distribution of different organisms in all categories of street food samples $(n=242)$ samples. Food samples collected in Monsoon $(n=46)$ and Spring $(\mathrm{n}=44)$ showed $37 \%$ and $18 \%$ contamination respectively. Only $7.35 \%$ showed contamination in winter season $(n=68)$.

We found contamination in 43 (18\%) from 242 food samples with E. coli, Shigella sp, and Vibrio sp. In the total 43 samples, $29(12 \%)$ were contaminated with E. coli, 12 (5\%) with Vibrio sp and $2(<1.0 \%)$ with Shigella sp. No Salmonella sp. was observed in street food samples. This is the second report of our findings regarding the food contamination in street vended items in different 20 University premises in Dhaka city. In our first report we observed contamination with Salmonella sp. (50\% samples), E. coli (46\%), Shigella sp. (20\%), and Vibrio sp. (2\%) in one University premises ${ }^{1}$.

In one study with food samples revealed that the highest frequencies of occurrence of pathogenic bacteria were $P$. aeruginosa (25\%), E. coli (32\%), S. aureus (27\%), Proteus sp. (45\%) and $36 \%$ Salmonella $\mathrm{sp} .{ }^{3}$ Study performed in Dhaka city, Bangladesh on the street vended ready-to-eat foods showed only $4.2 \%$ items were safe. A significant number of samples were coliforms and E. coli positive ${ }^{2}$. Our results corroborate with the findings of different reports regarding the presence of $E$. coli, Vibrio and Shigella sp. We also found highest contamination of food with $E$. coli (12\%) from 242 samples. Study conducted in Iran on 580 hospital food samples (both raw and cooked) were identified with highest prevalence of bacteria $(64.10 \%)$ in Summer ${ }^{11}$. We found majority of contamination of street foods (37\%) during Monsoon season. We also observed that 17 and $18 \%$ of food contamination occurred in Summer and Spring respectively. The results of our study suggest that due to excessive humidity, microorganisms grow enormously in Monsoon season of Bangladesh.

\section{Acknowledgement}

The authors are thankful to Incepta Pharmaceuticals Ltd., Dhaka, Bangladesh for providing all necessary reagents required to carry out this study.

\section{References}

1. Islam S, Nasrin N, Rizwan F, Nahar L, Bhowmik A, and Ahmed M. 2015. Microbial contamination of street vended foods from a university campus in Bangladesh. Southeast Asian J Trop Med Public Heal. 46(3): 480-5.

2. Hoque MA, Khatun MA, Shah F. Mohammad SF, Muhammad A, Masood T, Khan AZ and Faruquee HM. 2015. Microbiological Hazard Analysis and Exposure Assessment of Street Vended Ready-to-Eat Foods in Dhaka City, Bangladesh. Microbiological Hazard Analysis and Exposure Assessment of Am J Agric Environ Sci.15(9): 1725-31.

3. Tambekar DH, Jaiswal VJ, Dhanorkar DV, Gulhane PB and Dudhane $\mathrm{MN}, 2008$. Identification of microbiological hazards and safety of readyto-eat food vended in streets of Amravati City, India. J Appl Biosci. 7:195201.

4. Schirone M, Visciano P, Tofalo R and Suzzi G, 2017. Editorial/: Biological Hazards in Food. Front Microbiol. 7: 2016-8.

5. Tambekar DH, Kulkarni RV, Shirsat SD, and Bhadange DG, 2011. Bacteriological quality of street vended food Panipuri: A case study of Amravati City (MS) India. Biosci Discov. 2: 350-4.

6. Tambekar DH, Jaiswal VJ, Dhanorkar DV, Gulhane PB and Dudhane MN, 2009. Microbial Quality and safety of street vended fruit juices/ : A case study of Amravati city. Int. J Food Saf. 10: 72-6. 
7. Temesgen E, Eromo T, Tassew H, Daka D and Kibru G. 2016. Bacteriological Quality of Street Foods and Antimicrobial Resistance of Isolates in Hawassa, Ethiopia. Ethiop J Heal Sci. 26(6): 533-42.

8. Bereda TW, Emerie YM, Reta MA and Asfaw HS. 2016. Microbiological safety of street vended foods in Jigjiga City, Eastern Ethiopia. Ethiop $J$ Health Sci. 26(2):161-70.

9. Khairuzzaman M, Chowdhury FM, Zaman S, Al Mamun A and Bari ML. 2014. Food safety challenges towards safe, healthy, and nutritious street foods in Bangladesh. Int J Food Sci. 2014: 1-9.
10. Tabashsum Z, Khalil I, Nazimuddin M, Mollah AKMM, Inatsu Y and Bari ML. 2013. Prevalence of foodborne pathogens and spoilage microorganisms and their drug resistant status in different street foods of Dhaka city. Agric Food Anal Bacteriol J. 3(4): 281-92.

11. Ranjbar R, Masoudimanesh M, Dehkordi FS and Jonaidi-jafari N. 2017. Shiga (Vero)-toxin producing Escherichia coli isolated from the hospital foods; virulence factors, o-serogroups and antimicrobial resistance properties. Antimicrob Resist Infect Control. 6(4):1-11. 